\title{
Korelasi persentase lemak tubuh dengan kadar adipsin pada premenopause
}

Correlation between body fat percentage with adipsin levels on premenopause

\section{Rahmani Welan', Gusti Revilla², Desmawati ${ }^{3}$}

\author{
Program Studi Magister Ilmu Biomedik, Fakultas Kedokteran Universitas Andalas \\ ${ }^{2}$ Bagian Anatomi, Fakultas Kedokteran Universitas Andalas
}

${ }^{3}$ Bagian Ilmu Gizi, Fakultas Kedokteran Universitas Andalas

\begin{abstract}
Background: One of the conditions on premenopausal period is the increase in body fat, among which are caused by levels of the fluctuating estrogen hormone. Increase fat affects the body fat percentage and adipsin levels. Adipsin plays a role in the stimulation of insulin secretion by producing C3a, in which C3ARI (C3a Receptor 1) fragments interact with beta cells to secrete insulin. Objective: The purpose of this study is to determine correlation of body fat percentage with adipsin levels on premenopause. Method: This was an analytical study with cross-sectional design. Body fat percentage was obtained by examination using Bioelectrical Impedance Analysis (BIA). Venous blood was taken at the mediana cubiti area used for serum adipsin levels. Adipsin levels were analyzed by Enzyme-linked Immunosorbent Assay (ELISA) technique. Results: The mean of body fat percentage on premenopausal was $36,18 \pm 8,35 \%$. The mean of adipsin levels on premenopausal was 117,05 $\pm 87,93 \mathrm{ng} / \mathrm{ml}$. Result of Pearson test analysis got value $r=0,632$ and value $p=0.0005(p<0,05)$. Conclusion: There is a positive significant correlation between the percentage of body fat with adipsin levels on premenopause.
\end{abstract}

KEY WORDS: adipsin; body fat percentage; premenopause

\begin{abstract}
ABSTRAK
Latar belakang: Salah satu kondisi dalam masa premenopause adalah peningkatan lemak dalam tubuh, diantaranya disebabkan oleh kadar hormon estrogen yang berfluktuatif. Peningkatan lemak berpengaruh terhadap persentase lemak tubuh dan kadar adipsin. Adipsin berperan dalam stimulasi sekresi insulin dengan memproduksi C3a, sementara fragmen C3AR1 (C3a Receptor 1) berinteraksi dengan sel beta untuk mensekresi insulin. Tujuan: Tujuan penelitian ini adalah mengetahui korelasi persentase lemak tubuh dengan kadar adipsin pada premenopause Metode: Penelitian analitik dengan desain cross-sectional. Persentase lemak tubuh diperoleh dengan pemeriksaan menggunakan Bioelectrical Impedance Analysis (BIA). Selanjutnya, dilakukan pengambilan darah vena pada daerah mediana cubiti yang digunakan untuk pemeriksaan kadar adipsin dalam serum. Kadar adipsin dianalisis dengan teknik Enzyme-linked Immunosorbent Assay (ELISA). Hasil: Rerata persentase lemak tubuh pada premenopause sebesar $36,18 \pm 8,35 \%$. Rerata kadar adipsin pada premenopause sebesar 117,05 $\pm 87,93 \mathrm{ng} / \mathrm{ml}$. Hasil analisis uji Pearson didapatkan nilai $\mathrm{r}=0,632$ dan nilai $\mathrm{p}=0,0005(\mathrm{p}<0,05)$. Simpulan: Terdapat korelasi positif yang bermakna antara persentase lemak tubuh dengan kadar adipsin pada premenopause.
\end{abstract}

KATA KUNCI: adipsin; persentase lemak tubuh; premenopause

\section{PENDAHULUAN}

Setiap perempuan akan mengalami fase fisiologis dalam hidupnya, fase - fase tersebut diantaranya adalah premenopause, menopause, dan pascamenopause. Masa premenopause dimulai pada rentang usia 40 - 55 tahun. Data dari Badan Pusat Statistik (BPS) tahun 2010 menunjukkan bahwa sekitar 7.008.242 perempuan
Indonesia berusia 45 - 49 tahun dan di Sumatera Barat sekitar 139.681 jiwa perempuan sedangkan di Kota Padang sebanyak 25.433 perempuan berada pada rentang

Korespondensi: Rahmani Welan, Program Studi Magister Ilmu Biomedik, Fakultas Kedokteran Universitas Andalas, Jl. Perintis Kemerdekaan No. 49, Padang, Sumatera Barat, Indonesia, Telp.(0751) 841886,e-mail: rahmaniwelan@ gmail.com 
usia tersebut atau sekitar 5,7\% dari seluruh perempuan dari segala umur di Kota Padang (1-3).

Kondisi yang terjadi pada masa premenopause disebabkan oleh perubahan hormon. Salah satu hormon yang berperan dalam masa premenopause adalah estrogen. Estrogen memberikan efek yang responsif terhadap jaringan adiposa. Hormon estrogen berfungsi mengatur keseimbangan lemak tubuh dan menjaga lipolisis di jaringan lemak. Estrogen memiliki peran penting dalam proses adipogenesis. Estrogen meregulasi deposisi lemak dalam sel adiposa (4-6). Masa premenopause berhubungan dengan peningkatan massa lemak yang cepat dan redistribusi lemak ke abdomen. Modalitas radiologis menunjukkan terjadinya peningkatan massa lemak hingga memasuki masa pascamenopause. Hormon estrogen akan menyebabkan deposit lemak pada payudara, jaringan subkutan, pantat, dan paha perempuan (7).

Perempuan usia premenopause sampai pascamenopause (55-65 tahun) menghadapi masalah peningkatan berat badan. Prevalensi obesitas terus berlipat ganda hampir di seluruh dunia sejak tahun 1980 . Di negara maju dan berkembang, sebanyak 1,5 milyar orang dewasa di atas 20 tahun mengalami kegemukan (indeks massa tubuh atau IMT sebesar 25-29,9 kg/ $\mathrm{m}^{2}$ ). Analisis indeks massa tubuh (IMT) menunjukkan lebih dari 200 juta laki-laki dan kurang lebih 300 juta perempuan mengalami obesitas (IMT $\geq 30 \mathrm{~kg} / \mathrm{m}^{2}$ ). Riset Kesehatan Dasar (Riskesdas) pada tahun 2013 memperlihatkan adanya kecenderungan kenaikan prevalensi obesitas pada perempuan dewasa sekitar $32,9 \%$, naik 18,1\% dari tahun 2007 (13,9\%) dan 17,5\% dari tahun $2010(15,5 \%)(7,8)$.

Persentase lemak tubuh menggambarkan massa lemak dalam tubuh seseorang secara umum. Lemak dianggap organ endokrin yang mempunyai kemampuan untuk mensekresi adipokin dalam mempengaruhi aspek sistem keseimbangan energi dalam tubuh. Adipokin diregulasi oleh keadaan metabolik sehingga berhubungan dengan penyakit metabolik seperti resistensi insulin dan diabetes mellitus tipe $2(4,7)$. Adipokin (adipositokin) merupakan sitokin yang disekresikan oleh jaringan adiposa dan salah satunya adalah adipsin. Adipsin merupakan bagian dari serin protease. Adipsin adalah protein yang mRNA-nya diekspresikan jaringan adiposa putih dan coklat. Pada pasien obesitas, kadar adipsin menunjukkan angka yang lebih tinggi dibandingkan kontrol $(9,10)$.

Penelitian sebelumnya belum membahas secara spesifik bagaimana keadaan kadar adipsin terutama pada masa premenopause. Banyak penelitian yang lebih memfokuskan pada responden obesitas (11). Adanya kaitan antara persentase lemak tubuh dengan kadar adipsin pada penelitian sebelumnya tetapi belum pernah dibahas pada usia premenopause. Hasil penelitian di Harvard Medical School mengidentifikasi bahwa adipsin memiliki pengaruh terhadap sel beta pankreas, yang nantinya membantu menstimulasi pengeluaran insulin (12). Dengan demikian, tujuan penelitian ini adalah menganalisis korelasi persentase lemak tubuh dengan kadar adipsin pada premenopause.

\section{BAHAN DAN METODE}

Penelitian yang dilakukan merupakan penelitian observasional dengan desain penelitian cross sectional study yang dilaksanakan pada bulan Juli - November 2017. Populasi dalam penelitian adalah semua perempuan premenopause yang berada di Kota Padang. Pengambilan sampel dilakukan dengan pemilihan melalui kriteria inklusi dan eksklusi. Kriteria inklusi yaitu responden yang bersedia mengikuti penelitian dengan menandatangani informed concent, berusia 40 - 55 tahun pada saat dilaksanakan penelitian, tidak menggunakan kontrasepsi atau obat-obatan hormonal, dan tidak dalam pengobatan radioterapi atau kemoterapi. Sementara itu, kriteria eksklusi adalah responden yang tidak datang dan tidak dapat ditemui pada saat pengambilan data penelitian.

Besar sampel dalam penelitian dihitung dengan menggunakan rumus besar sampel untuk koefisien korelasi dengan nilai $Z_{\alpha}=1,96 ; Z_{\beta}=1,28$; dan perkiraan koefisien korelasi (r) berdasarkan penelitian sebelumnya sebesar 0,46 sehingga diperoleh jumlah sampel sebanyak 46 subjek dan ditambahkan untuk menghindari drop out sehingga jumlah sampel menjadi 51 subjek. Teknik pengambilan sampel yang digunakan dalam penelitian ini adalah multistage random sampling. Lokasi penelitian adalah di Kota Padang yang memiliki 11 kecamatan. Sebanyak 11 kecamatan tersebut dipilih secara acak 
untuk mendapatkan 4 kecamatan, kemudian dari 4 kecamatan dipilih kelurahan secara acak dan didapatkan 2 kelurahan untuk masing-masing kecamatan. Di tingkat kelurahan, dilakukan pemilihan secara acak untuk mendapatkan RW dan didapatkan 5 RW untuk masing - masing kelurahan. Pemilihan sampel pada tingkat RW menggunakan simple random sampling. Responden diberikan penjelasan mengenai tindakan yang akan dilakukan, tujuan, manfaat, dan kemungkinan timbulnya keadaan yang tidak menyenangkan dari tindakan tersebut kemudian responden mengisi persetujuan izin secara tertulis (informed consent).

Variabel independen pada penelitian ini adalah persentase lemak tubuh. Persentase lemak tubuh adalah besarnya massa lemak tubuh dibandingkan dengan total berat badan. Variabel dependen yaitu kadar adipsin yang merupakan kadar protease serin yang disekresikan oleh jaringan lemak. Berdasarkan The U.S. National Institutes of Health Criteria Standards for Percent Body Fat (PBF) dan American Dietetic Association (ADA) atau Canadian Dietetic Assosciation (CDA), nilai persentase lemak tubuh yang didefinisikan sebagai obesitas apabila persentase lemak tubuh pada laki-laki lebih dari atau sama dengan $25 \%$ dan perempuan lebih dari atau sama dengan $30 \%$.

Pengukuran tinggi badan responden menggunakan mikrotoa yang akan diinput dalam pemeriksaan Bioelectrical Impedance Analysis (BIA). Instrumen BIA yang digunakan adalah The Tanita $B C-418$ Body Composition Analyzer yang diproduksi Tanita The Standard, Arlington Heights, Illionis. Alat BIA dihidupkan kemudian akan muncul " 0,0 " pada bagian atas layar. Pilih tipe tubuh sesuai jenis kelamin, masukkan umur dan tinggi badan. Setelah input tinggi badan, akan muncul "GOAL" pada layar dan "step on". Berdiri di atas elektroda dan lihat nilai pada layar. Nilai impedans dengan menggenggam elektroda pada kedua alat pegangan BIA kemudian dicatat. Lebih lanjut, pengambilan darah vena dilakukan pada bagian vena median cubital. Sampel darah dimasukkan ke dalam tabung vakum dan disimpan dalam coolbox dengan suhu $0^{\circ} \mathrm{C}$. Transportasi sampel dilakukan segera pada hari yang sama (1 - 2 jam pengumpulan sampel darah) dengan menggunakan coolbox untuk dilakukan penyimpanan di Laboratorium Biomedik
Fakultas Kedokteran Universitas Andalas (FK Unand). Penyimpanan sampel dengan cara dibekukan pada freezer dengan suhu $-20^{\circ} \mathrm{C}$. Pemeriksaan kadar adipsin dilakukan dengan cara ELISA di Laboratorium Biomedik FK Unand. Normalitas data diketahui dengan menggunakan uji Kolmogorov-Smirnov sedangkan hubungan antara variabel independen dan variabel dependen dianalisis menggunakan uji korelasi Spearman. Penelitian ini telah lolos kaji etik dari Komite Etika Penelitian Fakultas Kedokteran Universitas Andalas dengan nomor 279/ $\mathrm{KEP} / \mathrm{FK} / 2017$.

\section{HASIL}

Hasil penelitian memperlihatkan rerata usia responden adalah $46,98 \pm 4,02$ tahun; rerata berat badan responden $58,48 \pm 12,32 \mathrm{~kg}$; rerata tinggi badan responden $149,88 \pm 5,94 \mathrm{~cm}$; dan rerata indeks massa tubuh (IMT) responden $25,96 \pm 4,83 \mathrm{~kg} / \mathrm{m}^{2}$. Usia yang paling banyak pada responden penelitian ini adalah 45 tahun. Hal ini memberikan gambaran bahwa sebagian besar responden melewati usia 45 tahun sudah mulai memasuki kondisi pre-obes yang terlihat dari rerata nilai IMT. Sebanyak 12 responden $(23,5 \%)$ dari penelitian ini memiliki IMT normal, 32 responden overweight $(62,7 \%)$, dan 7 responden obesitas $(13,7 \%)$.

Kadar adipsin (ng/ml)

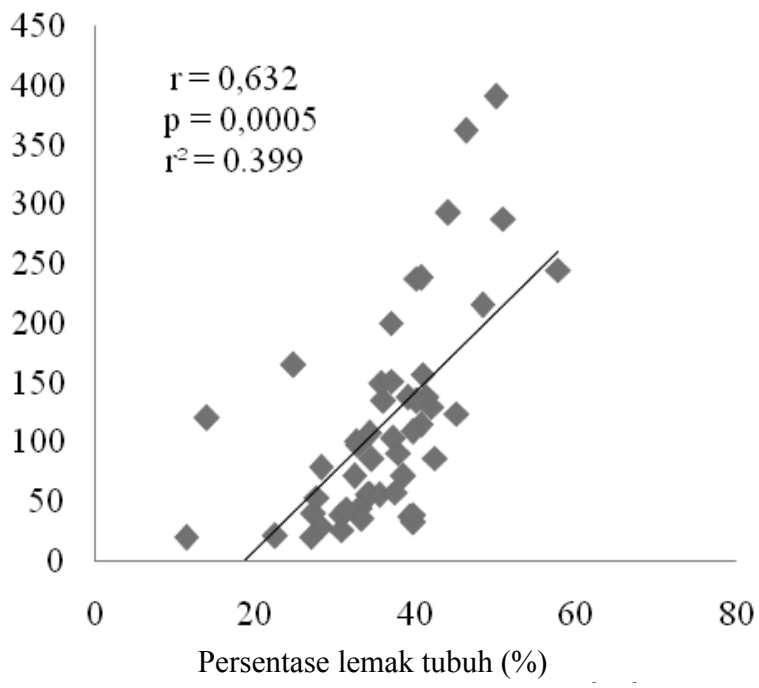

Gambar 1. Korelasi persentase lemak tubuh dengan kadar adipsin 
Rerata persentase lemak tubuh pada penelitian ini adalah 36,18 $\pm 8,35 \%$; rerata kadar adipsin sebesar $117,05 \pm 87,93 \mathrm{ng} / \mathrm{ml} ; 9$ responden mengalami kelebihan lemak tubuh $(17,6 \%)$; dan kadar adipsin responden tidak mengalami peningkatan yang signifikan jika dibandingkan dengan kadar adipsin pada responden sehat penelitian terdahulu.

Uji normalitas data menggunakan Uji KolmogorovSmirnov terhadap variabel umur, berat badan, tinggi badan, persentase lemak tubuh, dan kadar adipsin, diperoleh bahwa semua data terdistribusi normal $(p>0,05)$. Analsis korelasi pada Gambar 1 memperlihatkan korelasi yang kuat dan dan berpola positif antara persentase lemak tubuh dengan kadar adipsin $(r=0,632 ; p=0,0005)$.

\section{BAHASAN}

\section{Karakteristik berdasarkan persentase lemak tubuh}

Rerata hasil pemeriksaan persentase lemak tubuh pada penelitian ini adalah $36,18 \pm 8,35 \%$ dan dapat disimpulkan bahwa rata-rata pada usia premenopause mulai terjadi kenaikan dari persentase lemak tubuh melebihi kadar normal. Hal tersebut hampir sama dengan hasil penelitian yang dilakukan di United Kingdom pada 4.065 perempuan, dari segi persentase lemak tubuh dan usia terhadap penelitian ini, yaitu sebesar $36 \pm 8,4 \%$ dengan rerata usianya $44 \pm 12,9$ tahun. Hasil penelitian ini juga tidak jauh berbeda dengan penelitian di Iran pada 24 perempuan bahwa rerata usia 46,50 $\pm 3,98$ tahun memperlihatkan persentase lemak tubuh sebesar $38,83 \pm 2,75 \%(13,14)$.

Penelitian pada 352 perempuan di Brazil menunjukkan rerata persentase lemak tubuh pada rentang usia 40-50 tahun yaitu 39,6 $\pm 0,59 \%$ dan rentang usia 50-60 tahun yaitu $40,3 \pm 0,65 \%$. Hasil dalam penelitian tersebut juga berhubungan dengan penelitian sebelumnya yang menyebutkan bahwa Indonesia termasuk negara dengan persentase lemak tubuh yang tinggi, selain China, Jepang, Ethiopia, Thailand, dan Mexico. Analisis hasil penelitian ini juga hampir sama dengan hasil penelitian yang dilakukan pada 154 perempuan etnik Buryats dari kota Xinihe, China. Hasil persentase lemak tubuh penelitian tersebut pada rentang usia 40,46 $\pm 13,28$ tahun adalah $33,12 \pm 5,85 \%(15,16)$. Perbedaan dalam nilai persentase terdapat pada penelitian di China yang mendefinisikan obesitas dengan angka lebih dari $25 \%$ pada laki-laki dan lebih dari 35\% yang berpatokan pada penelitianpenelitian sebelumnya (15-17).

Penelitian di Jepang menyebutkan bahwa peningkatan massa lemak tubuh dimulai pada awal usia 40 tahun, baik pada laki-laki maupun perempuan. Lebih lanjut, penelitian di United Kingdom menemukan bahwa peningkatan persentase lemak tubuh terjadi karena peningkatan yang terus menerus pada massa lemak dan kurangnya aktivitas dari individu tersebut, yang dilakukan obeservasi pada orang dewasa sampai usia 50 tahun $(18,19)$. Dengan demikian, hasil penelitian ini menunjukkan adanya peningkatan persentase lemak tubuh seperti halnya penelitian-penelitian sebelumnya. Sebagian besar negara di dunia, perempuan pada usia premenopause sudah mulai terjadi penambahan lemak, termasuk di Indonesia. Hal ini menjadi suatu perhatian bahwa memasuki usia premenopause adanya kemungkinan penambahan persentase lemak tubuh yang bisa berefek terhadap kesehatan.

\section{Kadar adipsin pada responden penelitian}

Rerata kadar adipsin yang didapatkan dalam penelitian ini adalah 117,05 $\pm 87,93 \mathrm{ng} / \mathrm{ml}$. Rerata kadar adipsin dari penelitian ini tidak menunjukkan peningkatan yang signifikan jika dibandingkan dengan rerata kadar adipsin pada responden sehat penelitian sebelumnya. Penelitian yang dilakukan pada 75 perempuan dewasa dengan rerata usia 43,6 $\pm 10,9$ tahun di Arab Saudi memperlihatkan kadar adipsin sebesar $0,21 \mu \mathrm{g} / \mathrm{ml}$. Rerata kadar adipsin pada plasma dalam kondisi puasa adalah 1,5 $\mu \mathrm{g} / \mathrm{ml}$ dengan kisaran 1,2 - 1,6 $\mu \mathrm{g} / \mathrm{ml}$. Penelitian sebelumnya menyatakan bahwa kadar adipsin tidak jauh berbeda antara laki-laki dan perempuan. Kaitan antara adipsin dan persentase lemak tubuh dikaitkan dengan kejadian obesitas dan diabetes mellitus, yaitu tejadi kenaikan kadar adipsin dan insulin pada kondisi tersebut. Kadar adipsin meningkat pada obesitas sebesar $14-64 \%$ dan $22 \%$ pada penambahan berat badan, tetapi berkurang 19 - 40\% pada anorexia nervosa dalam beberapa penelitian $(20,21)$.

Sel adiposa merupakan salah satu komponen penting dari berbagai aktivitas fisiologis peptida, 
dianggap sebagai organ yang menjalankan aktivitas sinyal endokrin, parakrin, dan autokrin. Meskipun sebagian besar komponen yang disekresikan jaringan adiposa secara autokrin atau parakrin digunakan untuk meregulasi metabolisme sel adiposa, beberapa lainnya dilepaskan ke aliran darah untuk menuju ke tempat yang jauh secara aktivitas endokrin. Komponen - komponen tersebut dikenal dengan adipositokin. Adipsin merupakan adipositokin penting dari sel adiposa (22).

Adipsin adalah suatu enzim dengan berat molekul $28 \mathrm{kDa}$. Adipsin merupakan salah satu protein yang dapat berinteraksi antara jaringan adiposa dan jalur komplemen. Adipsin nantinya akan menstimulasi Acylation Stimulating Protein (ASP) yang akan meningkatkan sintesis trigliserida dalam sel. Kadar adipsin dan ASP dipengaruhi oleh asupan makan atau kondisi obesitas genetik (23). Adipsin merupakan bagian dari faktor komplemen dan juga diperlukan dalam fungsi sel $\beta$. Fungsi adipsin lainnya yaitu mengaktifkan jalur alternatif komplemen dan respon imun. Kadar adipsin meningkat atau tidak berubah pada orang dengan obesitas. Jumlah adipsin banyak di dalam jaringan adiposa dan aktivitasnya berada dalam jaringan tersebut $(24,25)$.

Adipsin dilepaskan sebagai adipokin yang tersedia banyak dalam darah. Berperan dalam metabolik dan sebagai sinyal sel yang dihasilkan oleh jaringan adiposa. Tugas adipsin sangat penting dalam metabolisme dan menstimulasi sekresi insulin dalam mengontrol gula darah. Adipsin memproduksi komplemen 3a (C3a) yang bekerja pada sel $\beta$ Langerhans yang berperan dalam menstimulasi insulin dan mampu mengurangi produksi glukosa hati. Peningkatan massa lemak diperkirakan meningkatkan sekresi adipsin untuk menstimulasi sel $\beta$ pankreas untuk memproduksi lebih banyak insulin sehingga insulin mampu meregulasi homeostasis energi dan metabolisme (15).

Adipsin disintesis selama lipolisis dan distimulasi oleh pusat lapar. Metabolisme lemak normal diatur secara bergantian oleh sekresi dari adipsin di saat lapar. Adipsin secara aktif diproduksi oleh sel adiposa yang berdiferensiasi di jaringan adiposa viseral. Adipsin bersama dengan ASP meningkatkan ambilan glukosa pada sel adiposa dan sintesis trigliserida. Peningkatan kadar adipsin dalam plasma darah terdeteksi pada pasien obesitas dan overweight (26). Adipsin adalah adipokin pertama yang ditemukan dan merupakan protein utama sel adiposa. Adipsin sebelumnya diidentifikasi sebagai faktor komplemen D yang mengkatalisis jalur alternatif dari aktivasi komplemen. Adipsin menstimulasi transpor glukosa dengan meningkatkan akumulasi trigliserida dalam sel lemak. Sistem adipsin - ASP terlibat dalam regulasi metabolisme trigliserida di sel adiposa. Sistem ini meningkatkan sintesis trigliserida di sel adiposa melalui translokasi transporter glukosa dari vesikula intraseluler ke memban plasma (27).

Korelasi antara sistem imun dan jaringan adiposa telah menghubungkan komplemen biologis dengan patogenesis diabetes mellitus tipe 2 . Hal ini dapat dijelaskan setidaknya sebagian protein tertentu dari jalur komplemen seperti adipsin sering terekspresi pada jaringan adiposa, subjek obesitas, dan diabetes mellitus tipe 2. Adipsin didentifikasi sebagai salah satu adipokin yang jumlahnya paling banyak dan secara khusus mengekspresikan protein adiposa yang menghubungkan sel lemak dan obesitas dengan fungsi sel beta. Adipsin dapat meningkatkan sekresi insulin dengan memproduksi C3A. Adipsin membagi komplemen faktor B pada jalur alternatif komplemen sehingga mengkatalisis pembentukan $\mathrm{C} 3$ covertase, yang selanjutnya berkontribusi terhadap hidrolisis kaskade yang menghasilkan berbagai fragmen komplemen termasuk komplemen 3a (C3A), C3b, C5a, dan C5b. C3a menginisiasi sekresi insulin yang disebabkan interaksi C3AR1 pada sel beta selama hiperglikemia dan tidak menginduksi sel beta untuk mengeluarkan insulin bila kadar glukosa rendah $(27,28)$.

Peningkatan kadar adipsin terlihat pada orang dengan obesitas. Penelitian di Amerika Serikat menyimpulkan konsentrasi adipsin berkaitan dengan perubahan lemak subkutan abdominal dan lemak total yang nantinya berkaitan dengan asupan makan yang berlebihan. Demikian halnya dengan perubahan berat badan berkaitan dengan perubahan kadar adipsin. Penelitian tersebut menunjukkan adanya pengaruh peningkatan lemak subkutan abdominal yang diinduksi oleh asupan makan yang berlebihan terhadap sedikit kenaikan dari kadar adipsin (29). Penelitian mengenai kadar adipsin pada usia premenopause belum banyak 
diteliti. Penelitian sebelumnya menemukan kadar adipsin dengan rerata yang cukup jauh dibandingkan dengan hasil penelitian ini sehingga belum memberikan gambaran yang jelas dari rerata kadar adipsin untuk usia premenopause.

\section{Korelasi persentase lemak tubuh dengan kadar adipsin}

Penelitian ini memperlihatkan hubungan persentase lemak tubuh dengan kadar adipsin dengan pola hubungan yang kuat dan berpola positif $(\mathrm{r}=0,632 ; \mathrm{p}=0,000)$. Hubungan ini juga terlihat pada penelitian yang dilakukan di Moravia Selatan terhadap 53 perempuan dengan rerata usia $51 \pm 9,81$ tahun bahwa rerata kadar adipsin yaitu $3,19 \pm 0,79 \mu \mathrm{g} / \mathrm{ml}$ dan rerata persentase lemak tubuh yaitu $51,43 \pm 5,01 \%$. Umur dan kadar adipsin berkorelasi positif $(r=0,368 ; p=0,008)$, serta persentase lemak tubuh dan kadar adipsin juga berkorelasi positif $(\mathrm{r}=0,577$; $\mathrm{p} \leq 0,001)$. Penelitian tersebut menyimpulkan bahwa kadar adipsin berkorelasi dengan peningkatan beberapa parameter yaitu usia, berat badan, IMT, dan persentase lemak tubuh. Penelitian tersebut menggunakan beberapa variabel untuk memprediksi persentase lemak tubuh, yaitu variabel umur, soluble leptin receptor, dan kadar adipsin. Perbedaannya terhadap penelitian ini adalah penggunaan variabel persentase lemak tubuh untuk memprediksi kadar adipsin (11).

Hasil penelitian di Slovenia menyimpulkan adanya korelasi positif antara persentase lemak tubuh dengan kadar adipsin. Penelitian tersebut dilakukan terhadap 52 perempuan premenopause obesitas dengan rentang usia 21-53 tahun dan rerata usia 40 8 tahun. Perbedaan dengan penelitian ini adalah subjek penelitian tersebut diikutsertakan dalam program reduksi berat badan selama 10-12 minggu dan dibandingkan dengan responden yang tergolong kurus. Rerata persentase lemak tubuh responden

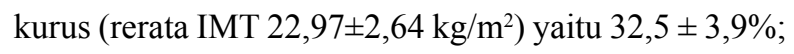
rerata persentase lemak tubuh responden pada awal program yaitu $38,8 \pm 4,0 \%$; setelah satu minggu sebesar $37,6 \pm 4,0 \%$; dan diakhir program menjadi $33,5 \pm 3,8 \%$. Rerata kadar adipsin pada awal program yaitu 2,1 $\pm 0,4$ $\mu \mathrm{g} / \mathrm{ml}$; setelah satu minggu yaitu $2,1 \pm 0,5$; dan di akhir program menjadi $2,0 \pm 0,4 \mu \mathrm{g} / \mathrm{ml}$, dibandingkan dengan responden kurus yaitu sebesar $1,4 \pm 0,2 \mu \mathrm{g} / \mathrm{ml}$. Hubungan persentase lemak tubuh dengan kadar adipsin juga terlihat pada penelitian ini dengan kekuatan hubungan sedang dan berpola positif $(r=0,46 ; p \leq 0,01)(30)$.

Berbeda dengan hasil penelitian di Iran yang menyebutkan hubungan yang tidak signifikan antara adipsin dan persentase lemak tubuh $(\mathrm{r}=-0,25 ; \mathrm{p}=0,433)$. Hal ini disebabkan oleh responden pada penelitian tersebut adalah wanita obesitas dengan diabetes mellitus tipe 2, sementara penelitian ini mengeksklusi responden dengan kondisi diabetes mellitus tipe 2. Lebih lanjut, penelitian di Rusia menemukan adanya penurunan kadar adipsin pada penderita diabetes mellitus tipe 2 walaupun nilai IMT dan lingkar pinggulnya bertambah $(14,26)$.

Persentase lemak tubuh menggambarkan massa lemak dalam tubuh seseorang secara umum. Akumulasi jaringan lemak dalam tubuh tergambar dari distribusinya, terutama pada lokasi lemak abdominal. Jaringan lemak atau jaringan adiposa merupakan suatu kelompok sel adiposa yang terorganisir yang terdiri dari dua tipe, yaitu jaringan adiposa putih (white adipose tissue - WAT)dan jaringan adiposa coklat (brown adipose tissue - BAT). Distribusi WAT lebih banyak secara anatomis yang tersebar luas di jaringan subkutan dan bertanggung jawab dalam penyimpanan lemak yang dikenal dengan istilah deposit lemak. Fungsi fisiologi WAT terlibat secara tiga garis besar, yaitu metabolisme lipid, metabolisme glukosa, dan fungsi endokrin. WAT digolongkan sebagai jaringan endokrin yang berperan dalam integrasi sinyalsinyal endokrin. WAT berperan sebagai penghasil zat bioaktif tertentu yang berperan dalam homeostasis proses fisiologis disebut adipokin atau adipositokin. Salah satu adipositokin yang disekresikan adalah adipsin $(11,22,31)$.

Jaringan adiposa tersebar diseluruh tubuh. Massa jaringan adiposa bervariasi pada setiap individu, sekitar $22 \%$ pada laki-laki obesitas dan $32 \%$ pada perempuan obesitas. Obesitas didefinisikan sebagai penyimpanan energi yang berlebihan pada WAT, yang terjadi karena ketidakseimbangan penggunaan energi dan asupan makan sehingga terjadi peningkatan penimbunan energi dalam bentuk lemak di dalam jaringan adiposa. Obesitas adalah kondisi penimbunan lemak yang berlebih dalam tubuh, terutama di dalam jaringan subkutan. Obesitas merupakan kondisi low grade inflammation 
kronik terutama pada WAT. Obesitas adalah gangguan keseimbangan energi, suatu kondisi yang menginduksi termogenesis. Ekspresi adipsin berhubungan dengan kecepatan termogenesis, keadaan hormonal atau jalur neuroendokrin yang mengontrol atau berpengaruh terhadap proses termogenesis. Peningkatan kadar adipsin pada jaringan adiposa obesitas mampu mengkompensasi respon normal dari parameter metabolisme karbohidrat dan lemak (12,26,32).

Lemak yang didapatkan dari asupan seharihari akan dimetabolisme menjadi asam lemak yang menstimulasi jalur intestine-brain-liver neural, yang pada akhirnya mengurangi produksi glukosa hati. Sebuah aksi kerja baru yang dipaparkan menyebutkan bahwa koneksi jaringan adiposa - sel langerhans juga membantu dalam meregulasi pengeluaran glukosa hati. Adipsin yang disekresikan jaringan adiposa akan memproduksi $\mathrm{C} 3 \mathrm{a}$ yang berinteraksi terhadap sel $\beta$ pancreas untuk menstimulasi insulin dan mengurangi produksi glukosa hati. Adipsin bekerja bersama dengan GLP-1 menambah sekresi insulin. Kerja adipsin dalam interaksinya dengan sel $\beta$ diharapkan mampu menjadi penanda diagnostik dan kemungkinan terapi untuk mengobati diabetes mellitus (33).

Dengan demikian, penelitian ini menunjukkan adanya peningkatan persentase lemak tubuh pada premenopause seperti hasil penelitian sebelumnya. Namun, hasil penelitian ini belum memberikan gambaran yang jelas dari rerata kadar adipsin untuk usia premenopause. Kekurangan penelitian ini adalah belum menggali pertanyaan mengenai riwayat obesitas sebelumnya, berat badan sebelum masa premenopause, dan riwayat penyakit gangguan imunitas atau inflamasi.

\section{SIMPULAN DAN SARAN}

Terdapat korelasi yang kuat, signifikan, dan berpola positif antara persentase lemak tubuh dengan kadar adipsin pada premenopause. Adanya perbedaan hasil antara beberapa penelitian sehingga membutuhkan penelitian lebih lanjut dengan kriteria responden dengan sindroma metabolik seperti diabetes mellitus tipe 2 dan adanya penyakit inflamasi.

\section{Pernyataan konflik kepentingan}

Penulis menyatakan tidak ada konflik kepentingan dengan pihak-pihak yang terkait dalam penelitian ini.

\section{RUJUKAN}

1. Badan Pusat Statistik. Penduduk menurut kelompok umur dan jenis kelamin. [series online] 2010 [cited 2017 Mei 14]. Available from: URL: http://www.bps.go.id

2. Soares CDN, Lee SC. The perimenopause, depresive disorder, and hormonal variability. Sao Paulo Med J 2001;119(2):78-83.

3. BPS Kota Padang. Padang dalam angka 2015. [series online] 2016 [cited 2017 Mei 14]. Available from: URL: http://padangkota.bps.go.id

4. Anwar M, Ali B, Prajitno P (eds). Ilmu kandungan. Jakarta: PT Bina Pustaka Sarwono Prawirohardjo; 2011.

5. Budiharjo S, Mansyur R, Djoko P. Pengaruh latihan fisik intensitas sedang terhadap persentase lemak badan wanita lanjut usia. Berkala Ilmu Kedokteran 2004;36(4):195200.

6. Setiawan M. Nutrisi kedelai pada obesitas dan dismetabolik sindrom. Saintika Medika 2010;6(2):1-8.

7. Davis SR, Camil CB, Peter C, Lumsden MA, Rossella EN, Paulina V, et al. Understanding weight gain at menopause. Climacteric 2012;15(5):419-29.

8. Putri SR, Dian IA. Obesitas sebagai faktor resiko peningkatan kadar trigliserida. Majority 2015;4(9):7882.

9. Choy LN, Barry SR, Bruce MS. Adipsin and an endogenous pathway of complement from adipose cells. J Biol Chem 1992;267(18):12736-41.

10. Pomeroy C, J Mitchell, E Eckert, N Raymond, R Crosby, AP Dalmasso. Effect of body weight and caloric restriction on serum complement proteins, including factor D/adipsin: studies in anorexia nervosa and obesity. Clin Exp Immunol 1997;108(3):507-15.

11. Flint E, Stevens C, Amanda S. Association between active commuting, body fat, and body mass index: population based, cross sectional study in The United Kingdom. BMJ 2014;349:1-9.

12. Azizi M, Vahid T, Naser B. The effect of aerobic exercise training on $\beta$-cell function and circulating levels of adipsin in community of obese women with type 2 diabetes mellitus. Int J Diabetes Dev Ctries 2017;37(3):298-304

13. Anjos LAD, Fabiana DCT, Vivian W, Mauricio TLV, Scott BG. Body fat pecentage and body mass index in a probability sample of an adult urban population in Brazil. Cad Saude Publica 2013; 29(1):73-81. 
14. Zhao D, Yonglan L, Lianbin Z, Keli Y. Brief communication: body mass index, body adiposity, and percent body fat in Asians. Am J Phys Anthropol 2013:1- 6 .

15. Zeng Q, Sheng YD, Xiao NS, Jing X, Yi C. Percent body fat is a better predictor risk factors than body mass index. Braz J Med Biol Res 2012;45(7):591-600.

16. Ito H, Ohshima A, Ohto N, Tsuzuki M, Takao K, Hijii C, Tanaka H, Nishioka K. Relation between body composition and age in healthy Japanese subject. Eur J Clin Nutr 2001;55(6):462-7.

17. Meeuwsen S, Gerard WH, Marinos E. The relationship between BMI and percent body fat, measured by bioelectrical impedance, in a large adult sample is curvilinear and influenced by age and sex. Clin Nutr 2010;29:560-6.

18. Al-Daghri NM, Abdulrahman SMAA, Hanan A, Sobhy MY, Naji Al, Sudhesh K, et al. Serum cytokine, chemokine, and hormone levels in Saudi adults with pre-diabetes: a one-year prospective study. Int J Clin Exp Pathol 2015;8(9):11587-93.

19. Cianflone K, Zhunan X, Lan YC. Critical review of acylation-stimulating protein physiology in human and rodent. Biochim Biophys Acta 2003;1609(2):127-43.

20. Avram, AS, Mathew MA, William DJ. Subcutaneous fat in normal and diseased state: 2 . Anatomy and physiology of white and brown adipose tissue. J Am Acad Dermatol 2005;53:671-83.

21. Badman, MK, Jeffrey SF. The adipocyte as an active participant in energy balance and metabolisme. Gastroenterology 2007;132(6): 2103-15.

22. Kloting N, Matthias B. Adipocyte dysfunction, inflamation, and metabolic syndrome. Rev Endocr Metab Disord 2014;15(4):277-87.
23. Aguilar-Valles, A, Wataru I, Christoph R, Giamal NL. Obesity, adipokines, and neuroinflamation. Neuropharmacology 2015;96:124-34.

24. Vasilenko MA, Kirienkova EV, Daria AS, Pavel AZ, Miroyuk NI, Larisa SL. The role of production of adipsin and leptin in The development of insulin resistance in patients with abdominal obesity. Dokl Biochem Biophys 2017;475(1):271-6.

25. Elekofehinti OO, Oluwamodupe CE, Jean PK, Oluwaseun BA, Isaac GA. Saponins as adipokine modulator : a possible therapeutic intervention for type 2 diabetes. World J Diabetes 2017;8(7):337-45.

26. Sramkova M, Michaela D, Jana V, Josef V, Petr M, Olga $\mathrm{B}$, et al. Levels of adipokines and some steroids during the menstrual cycle. Physiol Res 2015;64(2):147-54.

27. Ukkola O, Monique C, Tremblay A, Claude B. Genetic variation at the adipsin locus and response to long-term overfeeding. Eur J Clin Nutr 2003;57(9):1073-8.

28. Bienertova-Vasku J, Jan N, Filip Z, Martin F, Sona H, Anns V, et al. The prediction role of indexes of circulating adipokines for common anthropometric and nutritional characteristics of obesity in the obese central European population. Eat Behav 2014;15(2):244-51.

29. Mavri A, Mojca S, Michael K, Jozica TS, Margarethe $\mathrm{G}$, Bernard RB. Impact of adipose tissue on plasma plasminogen activator inhibitor-1 in dieting obese omen. Arterioscler Thromb Vasc Biol 1999;19:1582-7.

30. Rahmawati A. Mekanisme terjadinya inflamasi dan stres oksidatif pada Obesitas. El-Hayah 2014;5(1):1-8.

31. Wangko WS, Sunny W. Adipogenesis tumbuh kembang adiposit. Jurnal Biomedik 2010;2(3):153-61.

32. Susantiningsih T. Obesitas dan stres oksidatif. JuKe Unila 2015;5(9):89-93.

33. Baas T. Adipsin meets $\beta$ cells. SciBX 2014;7(30):1-3. 